\title{
Implantação de Brinquedoteca Hospitalar em Clínica Médica
}

\author{
Linhares, Daniela Ribeiro \\ Hospital Universitário da Universidade de São Paulo - HU-USP, São Paulo, Sp — \\ linhares75@hotmail.com
}

A hospitalização pode causar, em muitos indivíduos, mal-estar mental em contraposição à busca pela saúde, por isso, mesmo com a melhora da patologia, estes podem sentir-se deprimidos e desrespeitados devido a sua impotência neste momento, acarretando traumas e angústias que desequilibram sua relação com o meio. Acredita-se que a realização de atividades lúdicas/recreativas, durante a hospitalização, pode contribuir, efetivamente, para amenizar o estado ocioso mediante práticas educativas que estimulem a criatividade, a socialização, o interesse pela leitura e pela música, entre outras. Este estudo foi realizado na unidade de Clínica Médica (CM) de um hospital em São Paulo, com atendimento geral, nível secundário, com os objetivos de verificar se os pacientes internados expressam a necessidade de realizar atividades lúdico-recreativas e identificar quais atividades consideram possíveis de serem realizadas durante a internação. a coleta de dados foi realizada por meio de aplicação de formulário junto a 32 pacientes internados na CM. Os resultados evidenciaram que 31 participantes consideram importante a existência de um espaço ou momento com atividades recreativas. Foram citadas 148 atividades recreativas, sendo: ouvir música; usar papel e caneta para escrita de cartas, registro pessoal em diário e palavras cruzadas; realizar pinturas; participar de jogos como baralho dominó, quebra-cabeças, damas, xadrez, futebol, bilhar e comunitários estratégicos, leitura de livros; realizar trabalhos manuais como crochet, tricot, costura, culinária, fuxico e bordado. o estudo mostrou aos profissionais de saúde e educação que precisam ampliar suas ações, principalmente aquelas voltadas ao acolhimento do indivíduo, e reconhecer que, ao proporcionar a realização de atividades recreativas, estão favorecendo aos pacientes benefícios, dentre eles, o resgate da alegria. como resultado prático, este trabalho motivou a elaboração de um projeto que viabilizasse a implantação de uma brinquedoteca para adultos com o suporte dos grupo de voluntários vinculado ao hospital. a criação de um local apropriado para os pacientes internados na CM realizarem atividades lúdicos-recreativas, desde julho de 2007 até os dias atuais, permitiu a visibilidade da equipe ao ser brincante, independente de sua idade, além do investimento em novas tecnologias, como a instalação de computadores e wi-fi para a melhor conectividade do sujeito neste período em que a interface social é tão importante para sua recuperação.

Linhares, Daniela Ribeiro. Implantação de Brinquedoteca Hospitalar em Clínica Médica. In: Anais do Congresso Internacional de Humanidades \& Humanização em Saúde [= Blucher Medical Proceedings, num.2, vol.1]. São Paulo: Editora Blucher, 2014. ISSN 2357-7282

DOI 10.5151/medpro-cihhs-10738 